\title{
Adding wheat and rapeseed meal to corn-soy diets affects intestinal morphology and nutrient digestibility in broilers
}

\author{
E. Amirahmadi, A.R. Safamehr, A. Nobakht ${ }^{\#}$ \& Y. Mehmannavaz \\ Department of Animal Science, Maragheh Branch, Islamic Azad University, Maragheh, Iran
}

(Received 2 June 2020; Accepted ddmm2020; Published 29 November 2020)

\begin{abstract}
Copyright resides with the authors in terms of the Creative Commons Attribution 4.0 South African License.
See: http://creativecommons.org/licenses/by/4.0/za

Condition of use: The user may copy, distribute, transmit and adapt the work, but must recognize the authors and the South African Journal of Animal Science.
\end{abstract}

\begin{abstract}
This study was conducted to investigate the effects of thyme essential oil and enzyme supplementation on rations with two different energy (wheat or corn) and protein resources (soy or rapeseed meals) on gut morphology and protein digestibility of broiler chickens. Three hundred eighty-four male Ross308 broiler chickens were used with a $2^{3}$ factorial arrangement with treatments according to a completely randomized design. The morphological examinations of the intestine were carried out on $1-\mathrm{cm}$ long excised segments from duodenum, jejunum and ileum. Adding wheat to the diet increased small intestine length in birds compared to other feedstuffs $(P<0.05)$. Duodenum crypt depth and jejunum villi length were also higher in groups fed with rations containing wheat $(P<0.05)$. Groups that received thyme essential oil and enzyme supplementation had increased length of the duodenum $(P<0.05)$. However, the two- and threefactor interaction effects were not significant. Protein digestibility was not affected by treatment $(P>0.05)$. Feeding wheat to broiler chickens may increase the surface area for nutrient absorption in the small intestine as compensation for the anti-nutritive activity of non-starch polysaccharides in wheat-based diets. Wheat based diets are expected to be acceptable for broilers when supplemented with appropriate enzymes or thyme essential oil.
\end{abstract}

Keywords: enzyme supplementation, protein, rapeseed meal, soybean meal, thyme essential oil "Corresponding author: anobakht20@yahoo.com

\section{Introduction}

Non-starch polysaccharides (NSP) of cereal grains exhibit anti-nutritive activity when present in broiler diets (Annison \& Choct, 1991). In poultry, soluble NSP can increase digesta viscosity, reduce the digestibility of starch and protein and thus reduce growth performance (Choct et al., 2010) and increase the moisture content of litter (Dida, 2016; Tsiouris et al., 2020). Phytic acid found in wheat prevents the absorption of minerals such as iron, calcium, manganese, and zinc by binding to them before they can be absorbed in the small intestines (Lopez et al., 2002). Additionally, excess phosphorus in wheat grain is excreted and aggravates environmental problems (Nobakht et al., 2010). Chickens do not secrete the enzymes necessary to breakdown the NSP and phytate that are present in wheat and thus increase their utilization (Haribhau et al., 2020). In order to reduce these problems and increase the efficiency of wheat for use in poultry diets, different nutritional additives have been used as supplements. These supplements include organic acids and specific enzymes can be used in poultry diets especially containing highly levels NSP from grains such as wheat and rye (Shahir et al., 2012). Sharma et al. (2018) studied the use of enzyme supplementation in broiler diets substituting rice for corn on performance and the economics of meat production finding that higher doses of enzymes $(50 \mathrm{~g}$ on $100 \mathrm{~kg}$ feed) resulted in improved performance and reduced production costs.

As previously discussed by Nunes et al. (2015), the use of enzyme supplementation improved the performance of broilers by reducing the amount of nutrients and energy required. Moftakharzadeh et al. (2019) indicated that the use of enzymatic supplementation increased energy utilization from wheat and soybean based diets. Hussein et al. (2019) stated that adding enzymes to low-energy diets is an effective strategy to improve meat quality parameters and small intestine characteristics.

With the elimination of growth-promoting antibiotics from poultry diets, medicinal plants and their derivatives have been studied as alternatives to them (Hashemi \& Davoodi, 2010; Grashorn, 2010). These 
substances derived from medicinal plants have been shown to increase growth performance, improve health status (Dhama et al., 2014; Yadav \& Jha, 2019), and improve the intestinal microbiota (Al-Kassie, 2010; Kyaw et al., 2017).

Thyme (Thymus vulgaris) is a plant of the mint family. Its active constituents are thymol and carvacrol (Rabiei et al., 2011; Gursul et al., 2019) which can affect animal metabolism and physiology (Bouhtit et al., 2019). The active substances in thyme can stimulate secretion of pancreatic enzymes, thereby improving digestion efficiency and absorption of protein and other nutrients from the bird's gastrointestinal tract (EIHakim et al., 2009).

It is well known that small intestine is an important digestive organ and the main absorptive site of the gastrointestinal tract, but it is also immunological barrier in the gut to protect against incursion of endogenous microorganisms (Pickard et al., 2017; Cui et al., 2019). Fibre supplementation, such as would be provided by NSP, enhanced development of intestinal morphology and functional development in chickens (Yu et al., 2018; Saadatmand et al., 2019).

Therefore, it is reasonable to posit that effects of replacing corn with wheat on intestinal morphology require study. The condition of this part of the gastrointestinal tract can affect feed consumption and is useful for better understanding effects on measures of performance. The purpose of this research is to investigate the possibility of using wheat in poultry diets by also using enzyme and thyme essential oil supplements to mitigate the negative effects of NSP. Thus, the effects of replacing corn with wheat, soybean meal with rapeseed meal and using enzyme and thyme essential oil as supplements on intestinal morphology and nutrient digestibility were evaluated in broilers.

\section{Materials and methods}

The research animal ethics committee of Islamic Azad University approved this experimental protocol. A total of 384 male Ross-308 broilers (one-day-old) weighed before starting the trial. They were divided to treatments in a $2^{3}$ factorial arrangement consisting of grain type (corn and wheat), meal type (soybean and rapeseed) and additive type ( $0.2 \mathrm{ml}$ thyme essential oil and $100 \mathrm{gr} / \mathrm{ton}$ enzyme) with 32 plots.

Table 1 Nutritional contents of diets fed to broilers during the growing and finishing periods

\begin{tabular}{lcccccccc}
\hline & \multicolumn{3}{c}{ Growing period (11 to 24 days of age) } & \multicolumn{4}{c}{ Finishing period (25 to 42 days of age) } \\
\hline Corn & 54.87 & 47.75 & 33.61 & 31.09 & 54.39 & 53.16 & 33.60 & 29.15 \\
Soybean meal & 38.59 & 36.52 & 30.60 & 22.82 & 36.85 & 30.75 & 30.40 & 24.09 \\
Wheat & - & - & 30.00 & 30.00 & - & - & 30.00 & 30.00 \\
Rapeseed meal & - & 10.00 & - & 10.00 & - & 10.00 & - & 10.00 \\
Oil & 1.90 & 1.40 & 1.78 & 2.20 & 3.50 & 2.50 & 2.50 & 3.18 \\
Di-calcium phosphate & 1.95 & 1.90 & 1.60 & 1.47 & 1.45 & 1.50 & 1.40 & 1.36 \\
Calcium carbonate & 0.99 & 1.49 & 1.33 & 1.28 & 1.20 & 1.20 & 1.20 & 1.20 \\
Salt & 0.24 & 0.20 & 0.20 & 0.20 & 0.20 & 0.20 & 0.20 & 0.20 \\
Mineral & 0.25 & 0.25 & 0.25 & 0.25 & 0.25 & 0.25 & 0.25 & 0.25 \\
Vitamin & 0.25 & 0.25 & 0.25 & 0.25 & 0.25 & 0.25 & 0.25 & 0.25 \\
DL-Methionine & 0.37 & 0.14 & 0.28 & 0.30 & 0.01 & 0.001 & 0.018 & 0.17 \\
L-Lysine & 0.29 & - & - & 0.04 & 0.01 & - & - & 0.03 \\
Metabolisible energy, kcal/kg & 2950 & 2950 & 2950 & 2950 & 3000 & 3000 & 3000 & 3000 \\
Crude protein, \% & 21.20 & 21.20 & 21.20 & 21.20 & 18.75 & 18.75 & 18.75 & 18.75 \\
Calcium, \% & 0.96 & 0.83 & 0.83 & 0.95 & 0.84 & 0.84 & 0.84 & 0.84 \\
Available phosphorus, \% & 0.45 & 0.41 & 0.41 & 0.44 & 0.33 & 0.33 & 0.35 & 0.38 \\
Lysine, \% & 1.41 & 1.18 & 1.15 & 1.10 & 1.05 & 1.05 & 1.10 & 1.10 \\
Methionine, \% & 0.49 & 0.49 & 0.48 & 0.49 & 0.36 & 0.36 & 0.36 & 0.36 \\
Methionine + Cysteine, \% & 0.85 & 0.83 & 0.87 & 0.87 & 0.68 & 0.68 & 0.75 & 0.75 \\
\hline
\end{tabular}


At the end of the experiment when the birds were 42 days old, two birds were selected from each experimental unit for slaughter based on their body weight. The birds were fasted for 6 hours prior to slaughter. After slaughter, lengths of the duodenum, jejunum and ileum were recorded and samples were collected for subsequent histological evaluation.

The middle sections of the duodenum $(10 \mathrm{~cm}$ away from the pyloric junction), jejunum (proximal half of the remaining small intestine), and ileum ( $15 \mathrm{~cm}$ before the ileocecal junction) were aseptically isolated, flushed with $0.9 \%$ physiological saline solution. After fixation in $10 \%$ neutral buffered formalin, a single $0.5-$ $\mathrm{cm}$ sample was cut from each section, dehydrated with increasing concentrations $(70,80,95$, and $100 \%)$ of ethanol, cleared with xylene (Sub-X, Surgipath Medical Industries, Richmond, IL), and placed into polyfin embedding wax (Polysciences, Warrington, PA). Tissue sections $(5 \mu \mathrm{m})$ were cut, floated onto slides, stained with hematoxylin (Gill \#2, Sigma, St. Louis, MO) and eosin (Sigma), and measured for villus height and crypt depth using light microscopy and a micrometer. Measurements for villi length were taken from the tip of the villus to the valley between individual villi and measurements for crypt depth were taken from the valley between individual villi to the basolateral membrane (Burkholder et al., 2008).

The diets were formulated using the UFFDA software program (Pesti \& Miller, 1993) to provide the advised levels of nutrients as specified for the Ross-308 broiler. To measure digestibility, on day 42 of growth period, 2 birds were randomly selected from each experimental unit and after slaughter, ileum contents from $5 \mathrm{~cm}$ left in cecum, was collected.

Experiment was a factorial design conducted over a growing period from 11 to 24 days of age and finishing period from 25 to 42 days of age. There were four replicates of each treatment, each consisting of 12 birds. The data were analysed using the general linear model procedure of SAS (SAS Institute, Inc., Cary, North Carolina, USA). The linear model was:

$$
Y_{i j k l}=\mu+A_{i}+B_{j}+C_{k}+A B_{i j}+A C_{i k}+B C_{j k}+A B C_{i j k}+\varepsilon_{i j k l}
$$

where: $Y_{i j k l}=$ a dependent variable,

$\mu=$ overall mean,

$A_{i}=$ the effect of grain type (corn and wheat),

$B_{j}=$ the effect of meal type (soybean and rapeseed),

$C_{k}=$ the effect of additive type $(0.2 \mathrm{ml}$ thyme essential oil and $100 \mathrm{gr} / \mathrm{ton}$ enzyme),

$A B_{i j}=$ the interaction of grain and meal types,

$A C_{i k}=$ the interaction of grain and additive types,

$B C_{j k}=$ the interaction of meal and additive types,

$A B C_{i j k}=$ the interaction of grain, meal and additive types. and

$\varepsilon_{i j k l}=$ the residual deviation of the observation from the effects in the model.

Tukey's test at the $5 \%$ level of probability was used to compare means.

\section{Results and Discussion}

The significance of effects of the experimental treatments on intestinal morphology and protein digestibility are summarized in Table 2. None of the interaction effects were significant. Thus, the presentation of results and their discussion focuses on the main effects.

The lengths of all segments of the small intestine were significantly affected by the grain provided as the dietary base. Birds fed the diet that was based on wheat had a longer duodenum relative to their body weight than those fed the diet that was based on corn $(1.48 \pm 0.03 \mathrm{~cm}$ vs. $1.26 \pm 0.03 \mathrm{~cm}$, respectively). The main effect of the basal diet on jejunum length was also significant with the wheat based diet again producing greater length in this part of the small intestine than did the corn based diet $(3.84 \pm 0.02 \mathrm{~cm}$ vs. $3.39 \pm 0.02 \mathrm{~cm}$, respectively). Finally, as for the duodenum and jejunum, the length of the ileum was increased in those birds that received wheat relative to those fed corn $(2.47 \pm 0.04 \mathrm{~cm}$ vs. $2.25 \pm 0.04 \mathrm{~cm}$, respectively).

The length of the intestinal tract might have been increased in response to feeding wheat because it contains high levels of NSP which can increase the viscosity of the digesta. Increased viscosity of the digesta can lengthen the small intestine in more than one way. First, the more viscous digesta can exert a large amount of pressure on the lining of the intestine causing the muscle layers of the intestinal wall to relax. This relaxation results in increasing the length of the sarcomere and consequently the myofibrils of the muscle to counteract the pressure. In addition to increasing the length of the muscles in the intestinal wall, increased viscosity of the digesta can reduce their thickness is an adaptive mechanism to allow movement of the viscous material through the intestinal tract (Bederska-Łojewska et al., 2017; Kogut et al., 2017; Jha et 
al., 2019). Second, viscosity may increase the length of the intestine because a greater surface is required to satisfy the bird's need for nutrients (Kaczmarek et al., 2016; Rezaei et al., 2018). It is generally accepted that this increase in gut viscosity reduced the mixing of digestive enzymes and substrates in the intestinal lumen (Kaczmarek et al., 2016).

Table 2 Levels of probability from analyses of variance for the dependent variables that were recorded

\begin{tabular}{|c|c|c|c|c|c|c|c|c|}
\hline \multicolumn{2}{|c|}{ Dependent variable } & \multirow{2}{*}{$\begin{array}{c}\text { C vs. W (A) } \\
0.008\end{array}$} & \multirow{2}{*}{$\begin{array}{c}\text { S vs. R (B) } \\
0.068\end{array}$} & \multirow{2}{*}{$\begin{array}{c}\text { E vs. T (C) } \\
0.017\end{array}$} & \multirow{2}{*}{$\begin{array}{l}A \times B \\
0.715\end{array}$} & \multirow{2}{*}{$\begin{array}{l}A \times C \\
0.648\end{array}$} & \multirow{2}{*}{$\frac{B \times C}{0.244}$} & \multirow{2}{*}{$\frac{A \times B \times C}{0.974}$} \\
\hline Duodenum & length ${ }^{1}, \mathrm{~cm}$ & & & & & & & \\
\hline & Villus height, $\mu \mathrm{m}$ & 0.014 & 0.042 & 0.876 & 0.090 & 0.621 & 0.714 & 0.142 \\
\hline \multirow{3}{*}{ Jejunum } & Crypt depth, $\mu \mathrm{m}$ & 0.023 & 0.876 & 0.988 & 0.300 & 0.138 & 0.416 & 0.177 \\
\hline & length ${ }^{1}, \mathrm{~cm}$ & 0.027 & 0.097 & 0.058 & 0.316 & 0.945 & 0.246 & 0.449 \\
\hline & Villus height, $\mu \mathrm{m}$ & 0.011 & 0.912 & 0.927 & 0.918 & 0.227 & 0.354 & 0.149 \\
\hline \multirow{3}{*}{ Ileum } & Crypt depth, $\mu \mathrm{m}$ & 0.215 & 0.911 & 0.887 & 0.087 & 0.975 & 0.128 & 0.235 \\
\hline & length ${ }^{1}, \mathrm{~cm}$ & 0.001 & 0.122 & 0.088 & 0.784 & 0.615 & 0.228 & 0.061 \\
\hline & Villus height, $\mu \mathrm{m}$ & 0.341 & 0.616 & 0.936 & 0.567 & 0.618 & 0.587 & 0.364 \\
\hline & Crypt depth, $\mu \mathrm{m}$ & 0.641 & 0.349 & 0967 & 0.345 & 0.355 & 0.114 & 0.615 \\
\hline \multicolumn{2}{|c|}{ Protein digestibility, \% } & 0.310 & 0.987 & 0.793 & 0.649 & 0.812 & 0.352 & 0.150 \\
\hline
\end{tabular}

${ }^{1}$ length measurements were scaled to 100 grams of body weight

C vs W (A): effect of either corn or wheat as the dietary base, $S$ vs $R(B)$ : effect of adding rapeseed meal to the diet, $E$ vs $\mathrm{T}(\mathrm{C})$ : effect of supplemental enzyme or thyme essential oil

Yasar (2003) suggested that the length of the intestine of birds fed mixed rations with milled or whole grain wheat was significantly greater than that of control birds, which is consistent with the results of the present study. In contrast to these results, Wu et al. (2004) observed that whole wheat grain, although increasing gizzard weight and had no effect on the relative length of the small intestine. It is well known that the dietary content and amount of different fiber fractions may agitate physiological changes in the small intestine (Zduńczyk et al., 2013; Jankowski et al., 2013). More bioactive components, such as pentosan, may considerably affect intestinal viscosity, transit time, digesta moisture, and other indices of intestinal function (Kosmala et al., 2014).

Feeding broilers a diet based on corn versus one based on wheat significantly increased the height of villi in the duodenum (1187 $\pm 28 \mu \mathrm{m}$ vs. $1072 \pm 28 \mu \mathrm{m}$, respectively). However, this effect was reversed in the jejunum with the wheat based diet increasing the height of the villi compared to the corn based diet (388 $\pm 19 \mu \mathrm{m}$ vs. $321 \pm 19 \mu \mathrm{m}$, respectively). Feeding rapeseed meal in addition to soybean meal also increased the height of the villi in the duodenum (1143 \pm 28 vs. $1054 \pm 28 \mu \mathrm{m}$, respectively). In the ileum, height of the villi averaged $650.5 \mu \mathrm{m}$.

The intestinal villi are specialized structures that are very important for nutrient absorption of nutrients from the small intestine (Li et al., 2017; Groff-Urayama et al., 2019). By increasing the height of the villi, their surface area may become greater which can result in increased nutrient absorption (Marcos et al., 2019).

Regarding the depth of crypt, the main effect of basal diet was significant with the wheat-based diet producing greater crypt depth in the duodenum than the treatments containing corn $388 \pm 19 \mu \mathrm{m}$ vs. $321 \pm$ $19 \mu \mathrm{m}$, respectively). Average depth of crypts in the jujeum and ileum were 244.5 and $190.5 \mu \mathrm{m}$, respectively. The crypt can be considered the villus factory, and deep crypts indicate rapid tissue turnover and a high demand for new tissue (Wawrzyniak et al., 2017; Kim et al., 2018). Decreased crypt depth indicates a decrease in replacement of enterocytes which form the walls of the villi (Marcos et al., 2019).

In the ileum of the broilers, neither villus height nor depth of crypt was significantly influenced by any of the treatments that were imposed in the present study.

Those birds whose diet was supplemented with thyme essential oil also had a longer duodenum than the birds whose diet was supplemented with enzymes $(1.45 \pm 0.03 \mathrm{~cm}$ vs. $1.32 \pm 0.03 \mathrm{~cm}$, respectively). However, beyond this single observation, no other differences in intestinal morphology were observed between birds whose diet was augmented with either supplement. Several researchers reported that feed additives did not affect villus height (Houshmand et al., 2012) or width (Aliakbarpour et al., 2012; Fallah et al., 2013) compared with control groups. It has been reported that dietary exogenous enzymes improved the 
gut morphology of broiler chickens (Nabizadeh et al., 2017). However, the results of the present study indicate that the addition of dietary enzymes and thyme essential oil have similar effects on intestinal morphology.

While the basal diets altered intestinal morphology, they had no significant effect on protein digestibility in broiler chickens. Likewise, not significant effects were observed for the other treatments that were applied in this study, either singly or in combination. These results disagreed to previous report by Knap et al. (2011) who observed that broiler diets augmented with the probiotic B. subtilis significantly improved CP ileal digestibility and nitrogen retention compared to the control. Similarly, Zhang and Kim (2014) found that dietary supplementation with multi-strain probiotics improved ileal digestibility of amino acids and reduced ammonia content of the excreta.

\section{Conclusions}

Substitution of wheat for corn in broiler diets alters intestinal morphology with minimal effects on protein digestibility. Effects of adding rapeseed meal as another source of protein had benign effects on intestinal morphology. Effects of enzyme and thyme essential oil supplementation were similar. Interactions among these treatments were inconsequential. Based on these results and reports in related literature, wheat-based diets are expected to be acceptable for broilers when supplemented with appropriate enzymes or thyme essential oil.

\section{Acknowledgments}

The article was extracted from the Ph.D. thesis prepared by Edris Amirahmadi, under supervision of Prof. Alireza Safamehr and Prof. Ali Nobakht.

\section{Authors' Contributions}

EA collected the data for this study, YM conducted the statistical analyses, EA, AN and ARS developed the original hypotheses and designed the experiments, both authors have read and approved the finalized manuscript

\section{Conflict of Interest Declaration}

The authors declare that they have no known competing financial interests or personal relationship that could have appeared to influence the work reported in this paper.

\section{References}

Aliakbarpour, H.R., Chamani, M., Rahimi, G., Sadeghi, A.A. \& Qujeq, D., 2012. The Bacillus subtilis and lactic acid bacteria probiotics influences intestinal mucin gene expression, histomorphology and growth performance in broilers. Asian-Aust. J. Anim. Sci. 25, 1285-1293.

Al-Kassie, G.A. 2010. The role of peppermint (Mentha piperita) on performance in broiler diets. Agric. Biol. J. N. Am. 1(5), 1009-1013. https://doi.org/10.5251/abjna.2010.1.5.1009.1013

Annison, G. \& Choct, M., 1991. Anti-nutritive activities of cereal non-starch polysaccharides in broiler diets and strategies minimizing their effects. World's Poult. Sci. J. 47, 232-242.

Bederska-Łojewska, D., Świątkiewicz, S., Arczewska-Włosek, A. \& Schwarz, T., 2017. Rye non-starch polysaccharides: their impact on poultry intestinal physiology, nutrients digestibility and performance indices-a review. Ann. Anim. Sci.17(2), 351-369. https://doi.org/10.1515/aoas-2016-0090

Bouhtit, F., Najar, M., Agha, D.M., Melki, R., Najimi, M., Sadki, K., Lewalle, P., Hamal, A., Lagneaux, L., \& Merimi, M. 2019. The biological response of mesenchymal stromal cells to thymol and carvacrol in comparison to their essential oil: An innovative new study. Food Chem. Toxicol. 134, 110844. https://doi.org/10.1016/j.fct.2019.110844

Burkholder, K. M., Thompson, K. L., Einstein, M. E., Applegate, T. J., \& Patterson, J.A., 2008. Influence of stressors on normal intestinal microbiota, intestinal morphology, and susceptibility to Salmonella enteritidis colonization in broilers. Poult. Sci. 87(9), 1734-1741.

Choct, M., Dersjant-Li, Y., McLeish, J. \& Peisker, M., 2010. Soy Oligosaccharides and Soluble Non-starch Polysaccharides: A Review of Digestion, Nutritive and Anti-nutritive Effects in Pigs and Poultry. Asian-Aust. J. Anim. Sci. 23(10), 1386-1398.

Cui, Y., Wang, Q., Chang, R., Zhou, X. \& Xu, C., 2019. Intestinal barrier function-non-alcoholic fatty liver disease interactions and possible role of gut microbiota. J. Agric. Food Chem. 67(10), 2754-2762.

Dhama, K., Tiwari, R., Khan, R.U., Chakraborty, S., Gopi, M., Karthik, K. \& Sunkara, L.T., 2014. Growth promoters and novel feed additives improving poultry production and health, bioactive principles and beneficial applications: the trends and advances-a review. Int. J. Pharmacol. 10(3), 129-159. https://scialert.net/abstract/?doi=ijp.2014.129.159

Dida, M.F., 2016. Review paper on enzyme supplementation in poultry ration. Int. J. Bioorganic Chem. 1(1), 1-7.

El-Hakim, A.A., Cherian, G. \& Ali, M.N., 2009. Use of organic acid, herbs and their combination to improve the utilization of commercial low protein broiler diets. Int. J. Poult. Sci. 8(1), 14-20.

Fallah, R., Saghafi, M., Rezaei, H. \& Parvar, R., 2013. Effect of Bioplus 2B and Protoxin probiotics supplementation on growth performance, small intestinal morphology and carcass characteristics of broiler chickens. Br. J. Poult. Sci. $2,11-15$. 
Grashorn, M.A., 2010. Use of phytobiotics in broiler nutrition an alternative to infeed antibiotics. J. Anim. Feed Sci. 19(3), 338-347. https://doi.org/10.22358/jafs/66297/2010

Groff-Urayama, P., Padilha, J., Einsfeld, S., Pertile, S., Gorges, M., de Andrade, M. \& Takahashi, S., 2019. Performance, intestinal morphometry, and incubation parameters of broiler chickens submitted to in ovo feeding with different techniques and amino acids. Canadian J. Anim. Sci. 99(4), 732-740. https://doi.org/10.1139/cjas-2018-0131

Gursul, S., Karabulut, I. \& Durmaz, G., 2019. Antioxidant efficacy of thymol and carvacrol in microencapsulated walnut oil triacylglycerols. Food chem. 278, 805-810. https://doi.org/10.1016/j.foodchem.2018.11.134

Haribhau, G.A., Lakshmi, K.V., Alexander, G. \& Gurram, S., 2020. Effect of supplementation of multiple enzymes to the diets containing variable protein sources on performance and nutrient utilization in commercial broilers. Trop. Anim. Health Prod. 1-6. https://doi.org/10.1007/s11250-019-02185-6

Hashemi, S.R. \& Davoodi, H., 2010. Phytogenics as new class of feed additive in poultry industry. J. Anim. Vet. Adv. 9(17), 2295-2304.

Houshmand, M., Azhar, K., Zulkifli, I., Bejo, M.H. \& Kamyab, A., 2012. Effects of nonantibiotic feed additives on performance, immunity and intestinal morphology of broilers fed different levels of protein. S. Afr. J. Anim. Sci. 42 , 22-32.

Hussein, E.O., Suliman, G.M., Abudabos, A.M., Alowaimer, A.N., Ahmed, S.H., El-Hack, M.E.A. \& Laudadio, V., 2019. Effect of a low-energy and enzyme-supplemented diet on broiler chicken growth, carcass traits and meat quality. Arch. Anim. Breed. 62(1), 297. https://doi.org/10.5194/aab-62-297-2019

Jankowski, J., Zduńczyk, Z., Mikulski, D., Przybylska-Gornowicz, B., Sosnowska, E. \& Juśkiewicz, J., 2013. Effect of whole wheat feeding on gastrointestinal tract development and performance of growing turkeys. Anim Feed Sci. Technol. 185, 150-9. https://doi.org/10.1016/j.anifeedsci.2013.07.012

Jha, R., Singh, A.K., Yadav, S., Berrocoso, J.F.D. \& Mishra, B., 2019. Early nutrition programming (in ovo and post-hatch feeding) as a strategy to modulate gut health of poultry. Front. vet. sci. $6,82$. https://doi.org/10.3389/fvets.2019.00082

Kaczmarek, S. A., Hejdysz, M., Kubiś, M. \& Rutkowski, A., 2016. Influence of graded inclusion of white lupin (Lupinus albus) meal on performance, nutrient digestibility and intestinal morphology of broiler chickens. Br. Poult. Sci. 57(3), 364-374. http://dx.doi.org/10.1080/00071668.2016.1171295

Kim, D.H., Han, S.M., Keum, M.C., Lee, S., An, B.K., Lee, S. R. \& Lee, K.W., 2018. Evaluation of bee venom as a novel feed additive in fast-growing broilers. British Poult. Sci. 59(4), 435-442.

Knap, I., Kehlet, A.B. \& Bente, T.L., 2011. B. subtilis - improved protein digestibility and equal performance in energyreduced diets for broilers. Proc. 9th Poultry Research Days, Tours, France. 349-352.

Kogut, M. H., Yin, X., Yuan, J., \& Broom, L. J. 2017. Gut health in poultry. CAB Rev. 12(031), 1-7.

Kosmala M., Zduńczyk Z., Karlińska E. \& Juśkiewicz J., 2014. The effects of strawberry, black currant, and chokeberry extracts in a grain dietary fiber matrix on intestinal fermentation in rats. Food Res. Int. 64, 752-61. https://doi.org/10.1016/j.foodres.2014.07.010.

Kyaw, P.H.H., San Win, K., Lay, K.K., Moe, K.K., Maw, A.A. \& Swe, K.H., 2017. Effect of dietary garlic and thyme seed supplementation on the production performance, carcass yield and gut microbial population of broiler chickens. J. Scient. Agric. 269-274. https://doi.org/10.25081/jsa.2017.v1.872

Li, J., Miao, Z., Tian, W., Yang, Y., Wang, J. \& Yang, Y., 2017. Effects of different rearing systems on growth, small intestinal morphology and selected indices of fermentation status in broilers. Anim. Sci. J. 88(6), 900-908.

Lopez, H.W., Leenhardt, F., Coudray, C. \& Remesy, C., 2002. Minerals and phytic acid interactions: is it a real problem for human nutrition? Food Sci. + Tech. 37, 727-739. https://doi.org/10.1046/j.1365-2621.2002.00618.x

Marcos, M.J.L., Cauilan, J.D., Galam, D.R.A. \& Mangoba, A.G.C., 2019. Comparison of Small Intestinal Mucosa of Broiler Chicken Fed with Centrosema (Centrosema pubescens L.) Leaf Meal. European J. Agric. Food Sci. 1(2). https://doi.org/10.24018/ejfood.2019.1.2.11

Moftakharzadeh, S.A., Janmohammadi, H., Taghizadeh, A., Kianfar, R. \& Olyayee, M.G., 2019. Effect of enzyme addition on energy utilization and performance of broiler chickens fed wheat-based diet with different metabolizable energy levels. Acta Scientia. Anim. Sci. 41, e44585. https://doi.org/10.4025/actascianimsci.v41i1.44585

Nabizadeh, A., Golian, A., Hassanabadi, A. \& Zerehdaran, S., 2017. Effects of nutrient density and exogenous enzymes in starter diet on performance, intestinal microflora, gut morphology and immune response of broiler chickens. Rev. Bras. Cienc. Avic. 19, 509-518.

Nobakht, A., Rahimzadeh, M.R. \& Mehmannavaz, Y., 2010. Investigation the effects using different levels of Nettle (Urtica dioica), Menta pulagum (Oreganum valgare) and Zizaphora (Thymyus valgaris) medicinal plants in starter and grower periods on performance and carcasses traits of broilers. Proc 4th Iranian Congress of Anim. Sci. Pp. 40-44.

Nunes, J.O., Abreu, R.D., Brito, J.A.G, da Silva, R.F., Oliveira, L.S. \& Jesus, N.A., 2015. Enzyme supplementation of broiler feeds with reduced mineral and energy levels. Brazilian J. Poult. Sci. 17, 15-21. http://dx.doi.org/10.1590/1516-635XSPECIALISSUENutrition-PoultryFeedingAdditives015-022

Pesti, G.M. \& Miller, B.R., 1993. Animal Feed Formulation: Economic and Computer Applications. Springer- Netherlands, Heidelberg, Germany.

Pickard, J. M., Zeng, M. Y., Caruso, R. \& Núñez, G., 2017. Gut microbiota: Role in pathogen colonization, immune responses, and inflammatory disease. Immunol. Rev. 279(1), 70-89.

Rabiei, V., Shirzadeh, E., RabbiAngourani, H. \& Sharafi, Y., 2011. Effect of thyme and lavender essential oils on the qualitative and quantitative traits and storage life of apple Jonagold cultivar. J. Medicin. Plants Res. 5(23), 55225527. 
Rezaei, M., Karimi Torshizi, M. A., Wall, H. \& Ivarsson, E., 2018. Body growth, intestinal morphology and microflora of quail on diets supplemented with micronised wheat fibre. Br. Poult. Sci. 59(4), 422-429. https://doi.org/10.1080/00071668.2018.1460461

Saadatmand, N., Toghyani, M. \& Gheisari, A., 2019. Effects of dietary fiber and threonine on performance, intestinal morphology and immune responses in broiler chickens. Anim. Nut. 5(3), 248-255.

Shahir, M.H., Andalibi, V., Shivazad, M., Nia, A.H. \& Afsarian, O., 2012. Effect of different levels of full fat canola seed (with or without enzyme addition) on performance, carcass traits, and blood parameters in broilers. Iranian $\mathrm{J}$. Anim. Sci. 43(3), 337-345.

Sharma, R., Baghel, R.P.S., Sharma, S., Mishra, R.K., Nayak, S. \& Yadav, V., 2018. Effect of varying levels of enzyme supplementation with high levels of paddy replacing maize on the performance and economics of broiler production. J. Entomol. Zool. Stud. 6(4), 05-09.

Tsiouris, V., Kontominas, M. G., Filioussis, G., Chalvatzi, S., Giannenas, I., Papadopoulos, G. \& Georgopoulou, I., 2020. The Effect of Whey on Performance, Gut Health and Bone Morphology Parameters in Broiler Chicks. Foods. 9(5), 588.

Wawrzyniak, A., Kapica, M., Stępień-Pyśniak, D., Szewerniak, R., Olejarska, A. \& Jarosz, Ł., 2017. Effect of feeding transcarpathian zeolite on gastrointestinal morphology and function in broiler chickens. Brazilian J. Poult. Sci. 19(4), 737-746.

Wu, Y.B., Ravindran, V., Thomas, D.G., Birties, M.J. \& Hendriks, W.H,. 2004. Influence of method of whole wheat inclusion and xylanase supplementation on the performance, apparent metabolisable energy, digestive tract measurements and gut morphology of broilers. Br. Poult. Sci. 45, 385-394. https://doi.org/10.1080/00071660410001730888

Yadav, S. \& Jha, R., 2019. Strategies to modulate the intestinal microbiota and their effects on nutrient utilization, performance, and health of poultry. J. Anim. Sci. Biotechno. 10(1), 1-11. https://doi.org/10.1186/s40104-0180310-9

Yasar, S., 2003. Performance, gut size and ileal digesta viscosity of broiler chickens fed with a whole wheat added diet and the diets with different wheat particle sizes. Int. J. Poult. Sci. 2(1), 75-82.

Yu, J., Yang, H., Wang, Z., Dai, H., Xu, L. \& Ling, C., 2018. Effects of arginine on the growth performance, hormones, digestive organ development and intestinal morphology in the early growth stage of layer chickens. Italian J. Anim. Sci. 17(4), 1077-1082.

Zduńczyk, Z., Jankowski, J., Juśkiewicz, J., Mikulski, D. \& Slominski, B.A., 2013. Effect of different dietary levels of lowglucosinolate rapeseed (canola) meal and non-starch polysaccharide-degrading enzymes on growth performance and gut physiology of growing turkeys. Canadian J. Anim. Sci. 93, 353-362.

Zhang, Z.F. \& Kim, I.H., 2014. Effects of multistrain probiotics on growth performance, apparent ileal nutrient digestibility, blood characteristics, cecal microbial shedding, and excreta odor contents in broilers. Poult. Sci. 93(2), 364-370. https://doi.org/10.3382/ps.2013-03314 